(2) Open Access Full Text Article

REVIEW

\title{
Hip arthroplasty for treatment of advanced osteonecrosis: comprehensive review of implant options, outcomes and complications
}

This article was published in the following Dove Press journal:

Orthopedic Research and Reviews

28 June 2016

Number of times this article has been viewed

\section{Warit Waewsawangwong \\ Pirapat Ruchiwit \\ James I Huddleston \\ Stuart B Goodman}

Department of Orthopedic Surgery, Stanford University, Stanford, CA, USA
Correspondence: Stuart B Goodman Stanford University Medical Center

Outpatient Center, 450 Broadway Street, M/C 6342, Redwood City, CA 94063 ,

USA

$\mathrm{Tel}+|65072| 7629$

Fax + I 6507213470

Email goodbone@stanford.edu

\begin{abstract}
Surgical treatment for late stage (post-collapse) osteonecrosis of the femoral head is controversial. In these situations, the outcome of joint preservation procedures is poor. There are several arthroplasty options for late-stage disease. The clinical outcomes of hemiarthroplasty and hemiresurfacing are unpredictable because of progressive acetabular cartilage degeneration. Total hip resurfacing may be associated with further vascular insult to the femoral head and early failure of the implant. Total hip replacement with metal-on-conventional polyethylene bearing surfaces has been the gold standard, but implant survivorship is limited in young active patients due to wear and osteolysis. Newer alternative bearing surfaces may have improved wear characteristics, but their durability must be confirmed in longer-term studies.
\end{abstract}

Keywords: hip arthroplasty, advanced osteonecrosis, implant options, outcomes, complications

\section{Introduction}

Osteonecrosis is a phenomenon involving disruption of the vascular supply to the femoral head, resulting in articular surface collapse and eventual osteoarthritis. Osteonecrosis of the femoral head (ONFH) was first described in 1738 by Munro. In approximately 1835, Cruveilhier depicted morphologic changes of the femoral head secondary to interruption of blood flow. Since 1962, when Mankin described 27 cases of $\mathrm{ONFH}$, the number of reported cases of ONFH has increased steadily. Although alcoholism, steroid use, and hip trauma remain the most common causes, several other etiologies resulting in osteonecrosis have been identified.

ONFH is a debilitating disease that usually leads to osteoarthritis of the hip joint in relatively young adults (mean age at presentation 38 years). The disease prevalence is unknown, but estimates indicate that 10,000-20,000 new cases are diagnosed in the United States each year. ${ }^{1,2}$ Furthermore, it is estimated that $5 \%-18 \%$ of the more than 500,000 total hip arthroplasties performed annually are for ONFH. ${ }^{2}$ Late-stage (post-collapse) ONFH occurs when the femoral head is deformed and is no longer congruent with the acetabulum.

Mont et $\mathrm{al}^{3}$ reported a systematic review of untreated asymptomatic osteonecrosis and found that $49 \%$ of cases progressed to collapse of the femoral head after 49 months. Risk factors that affect head collapse include medium to large size (size more than $25 \%$ of the femoral head), location at the weight-bearing lateral two-thirds of the femoral head, and diseases such as sickle cell anemia. Once collapse occurs, optimum treatment is controversial. The outcome of joint preservation procedures in this late 
stage of disease is poor. Core decompression alone in Ficat stage III had success rates of only $21 \%-35 \%{ }^{4-6}$

The modified Ficat classification used for ONFH relies on a combination of plain radiographs of the hip, clinical signs and symptoms, and, more recently, magnetic resonance imaging. Stage III cases demonstrate clinical signs of pain and stiffness, and radiographs show the crescent sign and eventual cortical collapse. $^{7}$

There are few successful femoral head-preserving options for Ficat stage III osteonecrosis. One technique involves use of a "trap door" with nonvascularized bone grafting and has been reported to have a good or excellent result, as determined by the Harris hip scoring system, in $83 \%$ of cases. ${ }^{8,9}$ However, patient selection is crucial, including no history of steroid use, combined necrotic angle less than 200 degrees, and the need for containment osteotomy for a good outcome. ${ }^{8,9}$

Vascularized fibular grafts have a high rate of failure in the post-collapse stage. Survivorship was reported to be $64.5 \%$ at a mean of 4.3 years. ${ }^{10}$ Osteotomies of the proximal femur are another technique for treatment aimed at shifting the affected areas of the femoral head away from the major weight-bearing region of the joint. There are two general types of osteotomies, ie, angular intertrochanteric (varus/ valgus) and rotational transtrochanteric. In the post-collapse stage, the outcomes of angular and rotation osteotomies are less predictable, with failure rates up to $25 \%{ }^{11,12}$ at 5 years of follow-up for angular osteotomies, and 40\%-70\% ${ }^{13,14}$ at 4-7 years of follow-up for rotational osteotomies. The factors that influence the prognosis for optimal outcome are area of necrosis (surface involvement $<70 \%,{ }^{15}$ necrotic angle less than 200 degrees $^{16}$ ), etiology of disease (no history of high-dose corticosteroid use), ${ }^{8}$ stage of disease, ${ }^{8,17}$ extent of disease less than $2 \mathrm{~mm}$ of initial collapse, ${ }^{18}$ and surgical skill. Once the femoral head collapses or arthritis occurs on the acetabular side, the treatment of choice is reconstructive hip replacement. Various types of hip replacement, such as bipolar hemi-arthroplasty, hemiresurfacing, total resurfacing, and total hip arthroplasty, have been used in this population.

In this review, we summarize the indications, advantages/ disadvantages, results, and complications for each procedure in the post-collapse stage of ONFH in order to give the reader an overview of the surgical options for the treatment of patients in the different age groups.

\section{Limited femoral head resurfacing}

Because the acetabulum is relatively normal in Ficat stage III, the concept of hemiarthroplasty is appealing. Hemiresurfacing of the femoral head with cement fixation was developed and first performed in the early 1980s in young active patients to preserve femoral bone stock and permit later conversion to a total hip arthroplasty with less morbidity. ${ }^{19-23}$

Regarding the advantages of hemiresurfacing, the literature includes the following: only the degenerative cartilage and necrotic bone of the proximal femur are removed; bone stock of the femoral head and neck are preserved; revision to total hip arthroplasty is relatively easy; hemiresurfacing can delay the need for total hip arthroplasty; unlike a bipolar hemiarthroplasty, there is no polyethylene-bearing surface; and the dislocation rate is low.

However, there are limited indications for femoral resurfacing, including: young active patients presenting with Ficat stage III disease; lesions with a combined necrotic angle greater than 200 degrees or more than $30 \%$ of the femoral surface; a post-collapse lesion with more than $2 \mathrm{~mm}$ of femoral head depression; and no evidence of acetabular cartilage damage. ${ }^{24}$ The functional outcome in femoral resurfacing arthroplasty has been reported to yield significant improvement, ${ }^{25-27}$ and the short-term outcomes of hemiresurfacing were reported to be good/ excellent in $84 \%-88 \%$ of cases. ${ }^{21,27-29}$ However, the longterm survivorship of such implants decreased to $50 \%-60 \%$ at 10-11 years of follow-up ${ }^{22,27}$ (Table 1).

Squire et $\mathrm{al}^{30}$ reported a high overall failure rate of up to $64.8 \%$. The main causes of failure were unpredictable groin pain, further osteonecrosis, and fracture of the neck of femur. The prevalence of groin pain after limited resurfacing has been reported to be $20 \%-50 \%$. 22,26,31,32

The durability of acetabular cartilage after hemiresurfacing is multifactorial and includes the initial health of the cartilage (which should be totally unaffected) and the patient should not be symptomatic for long to obtain a successful outcome. ${ }^{27}$ A mismatch in the size of the femoral head compared with the inner diameter of the socket results in early failure. ${ }^{33}$ Other factors, such as lubrication and nutrition, third body wear, and patient activity, influence the outcome of limited resurfacing. ${ }^{33}$

Hungerford et $\mathrm{al}^{23}$ reviewed 33 femoral head resurfacings with post-collapse disease and found $61 \%$ had a good or excellent outcome prior to revision to total hip replacement at a mean interval of 60 months. The difficulty of performing total hip arthroplasty after limited resurfacing was almost equivalent to primary cases, because there was no loss of bone stock and the medullary canal of the femur was intact. ${ }^{22}$

Ash et $\mathrm{al}^{34}$ reported 58 hips converted to cemented total hip arthroplasty after cup arthroplasty. The survival rate after 
Table I Evidence for limited resurfacing in osteonecrosis of the femoral head

\begin{tabular}{|c|c|c|c|c|c|c|}
\hline Study & Prosthesis & Hips (n) & $\begin{array}{l}\text { Mean follow-up } \\
\text { (years) }\end{array}$ & $\begin{array}{l}\text { Success } \\
\text { rate }\end{array}$ & Survivorship & Cause of failure \\
\hline Amstutz et al ${ }^{22}$ & THARIES & 10 & 9.5 & $50 \%$ & $50 \%$ at II years & $50 \%$ groin pain \\
\hline Siguier et $\mathrm{a}^{35}$ & Marc Siguier & 37 & 4 & $76 \%$ & $76 \%$ & $\begin{array}{l}19 \% \text { further } \\
\text { collapse }\end{array}$ \\
\hline Cuckler et $\mathrm{al}^{31}$ & $\begin{array}{l}\text { Wright Medical } \\
\text { Conservprosthesis }\end{array}$ & 59 patients & 4.5 & $68 \%$ & $68 \%$ & $\begin{array}{l}40 \% \text { groin pain } \\
3 \% \text { fracture neck }\end{array}$ \\
\hline Adili et $\mathrm{al}^{32}$ & $\begin{array}{l}\text { Wright Medical } \\
\text { Conservprosthesis }\end{array}$ & 29 & 4 & $62 \%$ & $75.9 \%$ at 3 years & $\begin{array}{l}24 \% \text { groin pain } \\
3 \% \text { fracture neck }\end{array}$ \\
\hline Mont et $\mathrm{a}^{26}$ & Hemiresurfacing & 30 & 7 & $90 \%$ & $90 \%$ & $\begin{array}{l}20 \% \text { groin pain } \\
3 \% \text { fracture neck }\end{array}$ \\
\hline Beaule et $\mathrm{al}^{27}$ & Hemiresurfacing & 37 & 6.5 & $86 \%$ & $\begin{array}{l}79 \% \text { at } 5 \text { years } \\
59 \% \text { at } 10 \text { years } \\
45 \% \text { at } 15 \text { years }\end{array}$ & $\begin{array}{l}27 \% \text { groin pain } \\
3 \% \text { loosening } \\
\text { implant }\end{array}$ \\
\hline Scott et $\mathrm{a}^{21}$ & TARA & 25 & 3 & $88 \%$ & $88 \%$ & NA \\
\hline Hungerford et $\mathrm{al}^{23}$ & TARA & 33 & 10.5 & $61 \%$ & $61 \%$ at 5 years & $39 \%$ groin pain \\
\hline Sedel et $\mathrm{a}^{29}$ & Spherocylindric cup & 38 & 6 & $79 \%$ & $92 \%$ at 6.9 years & $\begin{array}{l}3 \% \text { infection } \\
6 \% \text { implant } \\
\text { loosening } \\
6 \% \text { neck } \\
\text { resorption }\end{array}$ \\
\hline
\end{tabular}

Abbreviation: NA, not available.

conversion was $92 \%$ at 10 years and $74 \%$ at 20 years. The cases did not require femoral bone grafting, and no fractures or femoral loosening occurred.

In conclusion, hemiresurfacing may be a procedure that "buys some time" for young patients. However, the results of hemiresurfacing are uncertain for several reasons, including unpredictable groin pain, further collapse of the head, and fracture of the femoral neck.

\section{Bipolar hemiarthroplasty}

The results of hemiarthroplasty involving the use of a fixedhead prosthesis have not been found to be acceptable for treatment of osteonecrosis..$^{36}$ The main reasons for the poor results are a high prevalence of destruction of the acetabular cartilage and bone stock by the prosthesis. Bipolar prostheses have been used to prevent erosion of the acetabulum and proximal implant migration, which frequently occur with monopolar Moore-type prostheses. These implants were initially developed by Charnley but popularized by Bateman ${ }^{37}$ and Giliberty ${ }^{38}$ in 1974. The purpose of the bipolar prosthesis is to decrease shear stress and impact loads on the acetabular cartilage, thereby reducing wear, and a big outer moving acetabular component is used to reduce dislocation and stem loosening. ${ }^{39}$

The indications for bipolar arthroplasty are reported to be the same as for hemiresurfacing. However, bipolar arthroplasty has disadvantages due to the requirement for resection of the femoral neck, engagement of the femoral canal, and use of a polyethylene-bearing surface which will generate wear debris and potentially compromise the longevity of the implant. Moreover, conversion arthroplasty to total hip replacement may need a very complex reconstruction, such as a roof ring, reconstruction cage, or other special implant (due to bone loss), and may require another revision later. ${ }^{40}$

The advantage of a bipolar prosthesis compared with a unipolar prosthesis is less proximal migration and supposedly better preservation of the acetabular cartilage.$^{41}$ In patients with osteoarthritis, the long-term outcome of bipolar prostheses in some series demonstrated healthy acetabular cartilage and bone at 15 years after surgery, ${ }^{42}$ and survivorship at $8-10$ years was acceptable at $89.5 \%-95 \%{ }^{43}$ However, in young active patients with ONFH, successful outcome of bipolar arthroplasty ranged from $59 \%$ to $95 \%$ (Table 2) and long-term survivorship was only $59 \%-86.3 \%$ at $10-15$ years of follow-up. ${ }^{39,44}$

Factors leading to early implant failure include persistent groin pain, proximal migration of the implant, and stem loosening. The prevalence of groin pain in patients with osteonecrosis has ranged from $11 \%$ to $53 \%$ (Table 2). Groin pain after bipolar arthroplasty may be caused by degeneration of the acetabular cartilage.

Lee et $\mathrm{a}^{45}$ compared the outcome of cementless bipolar arthroplasty and cementless total hip replacement in matched controlled patients with stage III osteonecrosis, and found the prevalence of groin pain and gluteal pain in the bipolar group was $35 \%$ while groin pain was absent in total hip replacements $(P=0.014)$. The treatment of intractable groin 
Table 2 Evidence for bipolar hemiarthroplasty in osteonecrosis of the femoral head

\begin{tabular}{|c|c|c|c|c|c|}
\hline Study & Prosthesis & $\begin{array}{l}\text { Hips } \\
\text { (n) }\end{array}$ & $\begin{array}{l}\text { Mean follow-up } \\
\text { (years) }\end{array}$ & Survivorship & Causes of failure \\
\hline Cabanela $^{39}$ & Bateman & 23 & 9.2 & $78 \%$ & Groin pain $36 \%$ \\
\hline \multirow[t]{3}{*}{ Chan and Shih" ${ }^{46}$} & Omifit (osteonic) & 28 & 6.4 & $96 \%$ & Proximal migration $10.7 \%$ \\
\hline & & & & & Groin pain $10.7 \%$ \\
\hline & & & & & Femoral osteolysis $3.6 \%$ \\
\hline \multirow[t]{4}{*}{ Meijerink et al ${ }^{47}$} & Omifit (osteonic) & 30 & 10.4 & $73 \%$ & Proximal migration $60 \%$ \\
\hline & Hydroxyapatite/nonhydroxyapatite & & & & Subsidence $37 \%$ \\
\hline & & & & & Groin pain $53 \%$ \\
\hline & & & & & Femoral osteolysis $63 \%$ \\
\hline \multirow[t]{2}{*}{ Ito et $\mathrm{al}^{48}$} & Omifit (osteonic) & 48 & 11 & $70 \%$ at 15 years & Groin pain $42 \%$ \\
\hline & & & & & Proximal migration $42 \%$ \\
\hline \multirow[t]{3}{*}{ Lee et $\mathrm{al}^{45}$} & Spongiosa I & 40 & 8 & NA & Groin pain $20 \%$ \\
\hline & & & & & Proximal migration $23 \%$ \\
\hline & & & & & Dislocation $5 \%$ \\
\hline Murzic and & Bateman & 32 & 6 & $81 \%$ & Proximal migration $6 \%$ \\
\hline McCollum ${ }^{49}$ & & & & & Groin pain $18 \%$ \\
\hline \multirow[t]{3}{*}{ Nagai et a ${ }^{44}$} & Bateman & 12 & 16.6 & $75 \%$ & Groin pain 33\% \\
\hline & & & & & Osteolysis I7\% \\
\hline & & & & & Migration of stem $8 \%$ \\
\hline \multirow[t]{3}{*}{ Takaoka ${ }^{41}$} & Various & 83 & 5.7 & NA & Groin pain $17 \%$ \\
\hline & & & & & Proximal migration $8.4 \%$ \\
\hline & & & & & Loosening $17 \%$ \\
\hline
\end{tabular}

Abbreviation: NA, not available.

pain in patients with bipolar arthroplasty is conversion to total hip replacement. However, groin pain may not resolve after conversion. Pankaj et $\mathrm{al}^{50}$ reported that $83 \%$ of patients with bipolar arthroplasty converted to total hip replacement had no pain postoperatively while three patients $(17 \%)$ reported only partial improvement.

The second cause of failure of bipolar prostheses is radiographic stem subsidence. The prevalence of stem loosening in osteonecrosis has been reported to be $8 \%-37 \%{ }^{44,46,47,51}$ Early loosening of the stem is caused by poor canal fit, such as with Moore-type stems, which showed a high prevalence of loosening (47\%) compared with the press fit Omnifit stem $(6 \%) .{ }^{41}$ Periprosthetic osteolysis is another cause of stem loosening.

Kim and Rubash ${ }^{52}$ reported that polyethylene debris in bipolar arthroplasty was significantly higher than in matchedcontrol cementless total hip replacements $(P<0.05)$, and caused osteolysis and aseptic loosening. The prevalence of femoral osteolysis in bipolar prostheses in patients with osteonecrosis has varied from $4 \%$ to $63 \%$ at a mean follow-up of 6-10 years. ${ }^{46,47,53}$ Meijerink et al ${ }^{41}$ reported a high prevalence of femoral osteolysis (63\%) with the Omnifit stem, and an inferior locking mechanism caused a high amount of polyethylene wear debris and extensive osteolysis, especially in young active patients.

In conclusion, bipolar arthroplasty for osteonecrosis has a high failure rate and unpredictable results. Furthermore, the use of bipolar arthroplasty violates the femoral canal and maintains a polyethylene-bearing surface, which will generate wear debris and potentially compromise the longevity of the implant. Conversion to total hip replacement may require complex reconstruction and another revision later on.

\section{Resurfacing hip arthroplasty}

Limited resurfacing may be an option in young patients without evidence of acetabular disease (Ficat stage III), but the outcome is guarded. Pain relief is not predictable, especially when there is evidence of articular cartilage involvement. In this setting, total hip resurfacing may be a better option. The advantages of total resurfacing are a low wear rate, preservation of bone stock for further revision, use of a large diameter head to reduce dislocation rate, improved function as a consequence of the retained femoral head and neck, more precise biomechanical restoration, and decreased morbidity at the time of revision arthroplasty. ${ }^{54}$ First-generation (metal-on-polyethylene) and secondgeneration (cementless metal-on-metal) total resurfacing were abandoned because of failures from high volumetric wear resulting in osteolysis and loosening. ${ }^{55}$

Third-generation total resurfacing began in 1996, and cementless acetabular fixation combined with a cemented femoral component has been shown to be more durable. The combination of a large-diameter metal-on-metal bearing surface has shown a low wear rate after several decades of use. ${ }^{56}$ 
However, a recent study showed that small diameter femoral components (less than $51 \mathrm{~mm}$ ) are a risk factor for increased wear, corrosion, and higher metal ion concentration levels in the blood. ${ }^{57}$ Conditions such as inflammatory arthropathy, osteonecrosis, and developmental hip dysplasia have been associated with higher rates of early failure. ${ }^{58}$

Osteonecrosis is a disease of bone substance which is different from osteoarthritis. Moreover, patients with advanced osteonecrosis often have associated risk factors, such as continued alcohol abuse or corticosteroid use, which compromise bone quality and the surface area available for implant fixation, resulting in continued femoral head collapse. ${ }^{59}$ A contraindication for hip resurfacing is a necrotic area involving more than $50 \%$ of the femoral head (regardless of Ficat stage).

According to the US Food and Drug Administration protocol, Seyler et $\mathrm{l}^{60}$ have developed a guideline algorithm for decision-making to proceed to resurfacing or total hip replacement. The algorithm has been based on gender, age, and etiology of disease. In patients with osteonecrosis, candidates for resurfacing must have a necrotic area less than $35 \%$ preoperatively, normal configuration of the proximal femur intraoperatively, no femoral head cysts, no head-neck junction abnormality, no large bone defects, and a neck-shaft angle of more than 120 degrees. Similarly, Revell et al ${ }^{61}$ used three criteria to decide whether to proceed to hip resurfacing intraoperatively, ie, if the femoral head had a necrotic area of less than $35 \%$, the integrity of the head-neck junction was preserved, and good bone stock remained after femoral preparation. They reported survivorship of Corin resurfacing implants to be $93.2 \%$ at a mean follow-up of 6 years.

The successful outcome and survivorship of thirdgeneration total resurfacing was greater than $93 \%$ at 3-7.5 years of follow-up ${ }^{59-64}$ (see Table 3 ). When compared with osteoarthritis, Mont et $\mathrm{al}^{62}$ and Aulakh et $\mathrm{al}^{64}$ found no significant difference in survivorship or outcome between osteonecrosis and a matched cohort of patients with osteoarthritis.

However, serious complications after total or hemiresurfacing leading to early unexpected failure of the implant may occur, and include progressive osteonecrosis (collapse) and femoral neck fracture. In Australia, the most common reason for revision of resurfacing has been femoral neck fracture. ${ }^{65}$

There is evidence that mechanical risk factors, such as notching of the superior part of the femoral neck during implantation, incomplete seating or varus alignment, and postoperative lengthening of the femoral neck are commonly associated with subsequent femoral fracture. ${ }^{66}$ Further osteonecrosis as a result of femoral head resurfacing may play a role in femoral neck fracture. ${ }^{67}$

Steffen et $\mathrm{al}^{68}$ compared biopsies in 19 retrieved femoral head resurfacings that failed as a result of neck fracture with 13 retrieved femoral head resurfacings that failed for other reasons. Histologic analysis showed empty lacunae in a large proportion of both groups. These researchers found empty lacunae in $9 \%$ of control patients with osteoarthritis undergoing primary total hip replacement compared with $85 \%$ of those with osteonecrosis $(P<0.01)$. In the revision situation, $71 \%$ in the neck fracture group and $21 \%$ of the other group $(P<0.01)$ demonstrated empty lacunae.

McMinn et $\mathrm{al}^{69}$ reported 104 hip resurfacings (94 patients) for osteonecrosis Ficat stage III and IV at a mean follow-up of 4.3 years. They found four hips $(3.8 \%)$ had further collapse of the femoral head compared with $0.35 \%$ further collapse in other diagnoses.

In osteonecrosis, the femoral head has already had a vascular insult, so the question is how to prevent further vascular damage during the surgical procedure. The extraosseous blood supply of the femoral head from the

Table 3 Evidence for total resurfacing in osteonecrosis of the femoral head

\begin{tabular}{|c|c|c|c|c|c|}
\hline Study & Prosthesis & Hips (n) & Mean follow-up (years) & Survivorship & Causes of failure \\
\hline \multirow[t]{2}{*}{ Mont et $\mathrm{al}^{62}$} & Conserve plus & 42 & 3.4 & $94.5 \%$ & $2 \%$ fracture neck \\
\hline & & & & & $2 \%$ femoral loosening \\
\hline \multirow[t]{2}{*}{ Sayeed et $\mathrm{al}^{63}$} & Conserve plus and & 20 (age $<25$ years) & 5 & $100 \%$ at 7.5 years & None \\
\hline & Corin comet 2000 & & & & \\
\hline \multirow[t]{2}{*}{ Sayeed et $\mathrm{al}^{63}$} & Conserve plus and & 87 (age > 25 years) & 6 & $94 \% *$ & $6 \%$ aspetic reasons \\
\hline & Corin comet 2000 & & & & \\
\hline Aulakh et $\mathrm{al}^{64}$ & Birmingham & 101 & 7.5 & $98 \%$ & $2 \%$ fracture neck \\
\hline \multirow[t]{3}{*}{ Revell et $\mathrm{al}^{61}$} & Corin and Birmingham & 73 & 6 & $93 \%$ & I\% femoral loosening \\
\hline & & & & & I\% further collapse \\
\hline & & & & & I\% subtrochanteric fracture \\
\hline Beaule et $\mathrm{al}^{59}$ & Conserve plus & 28 & 4.5 & $93 \%$ & $7 \%$ femoral loosening \\
\hline
\end{tabular}

Note: *No difference $(P=0.58)$ between the 7.5 years of survivorship in the groups under and over 25 years of age. 
medial circumflex artery can be destroyed during the posterior approach. In the standard posterior approach, the medial circumflex artery is divided, decreasing blood flow to the head. Other procedures performed using the posterior approach, such as tenotomies of the short external rotators and dissection of the capsule distal to the piriformis, are likely to damage the branches of the medial femoral circumflex artery and potentially render the femoral head avascular. ${ }^{66,70-72}$ Preserving the attachment of the obturator externus protects the ascending branch of the medial circumflex artery from injury.

Steffen et $\mathrm{al}^{66}$ reported the effect of resurfacing on oxygen concentration of the femoral head with an extended posterior approach, causing a mean $60 \%$ decrease in oxygen concentration that did not improve significantly after wound closure. The surgical dislocation approach described by Ganz et $\mathrm{al}^{73}$ (anterior surgical dislocation and trochanteric flip) has been developed to preserve vascularity of the femoral head.

Amarasekera et $\mathrm{al}^{71}$ used laser Doppler flowmetry to measure the effect on blood flow to the femoral head-neck junction of two surgical approaches during resurfacing arthroplasty and found that the main reduction in blood flow occurred during exposure and capsulotomy in both groups. There was a significantly greater reduction in blood flow with the posterior approach $(40 \%)$ than with the trochanteric flip approach $(11 \%, P<0.01)$. Reaming the femoral head is another procedure that can damage blood flow to the femoral head.

Beaulé et $\mathrm{al}^{74}$ reported ten hips with advanced osteoarthritis having metal-on-metal hip resurfacing by means of the Ganz surgical dislocation approach which had femoral head blood flow measurements using laser Doppler flowmetry. Nine hips had a mean decrease of $70 \%$ in femoral head blood flow after standard reaming $(P=0.0003)$. They concluded that the cylindrical reamer substantially compromised blood flow to the femoral head by encompassing the whole circumference of the femoral head-neck junction, potentially disrupting all of the retinacular vessels. To preserve the blood supply while reaming, one must direct the cylindrical reamer superolaterally, staying as close as possible to the inferomedial neck. The final step that can be harmful to the viability of the femoral head is cement preparation.

Campbell et al $^{75}$ retrieved failed metal-on-metal resurfacings from femoral neck fracture or loosening and compared these cases with other causes of failure. They found that the total percentage of the femoral head section occupied by cement ranged from $11 \%$ to $89 \%$ in the femoral neck fracture/loosening group. The temperature was high enough to produce thermal necrosis of the femoral head. Because of this, excessive cement penetration may result in necrosis of bone secondary to the heat of polymerization and may cause early failure of the implant.

In conclusion, the short-term to mid-term outcome of total resurfacing in ONFH has been reported to be excellent in young patients. However, total resurfacing in the osteonecrotic femoral head has some issues for concern. Patient selection is crucial, and femoral heads with extensive necrosis that would require shortening or downsizing to resect dead bone may be better served by total hip replacement. Long-term outcome and the prevalence of unexpected failure in the patient with osteonecrosis should be monitored closely.

\section{Total hip replacement}

Total hip arthroplasty is indicated in advanced stage osteonecrosis once the femoral head has collapsed and the hip joint has degenerated. However, the longevity of total hip arthroplasty for treatment of osteonecrosis is less when compared with other indications. ${ }^{76-79}$ There are several factors that contribute to the high failure rate. ${ }^{80}$ Age is the most important factor that affects the outcome of total hip replacement. ${ }^{81}$ The age at presentation of nontraumatic osteonecrosis has been reported to range from 24 to 65 years, and $75 \%$ of these patients are aged $30-60$ years. ${ }^{82,83}$ Younger patients have a higher activity level, increased wear, and osteolysis. Young age at the time of surgery has been associated with mechanical failure in $14 \%-37 \%$ of total hip replacements at a mean follow-up of 6-7.5 years. ${ }^{78,79,81,84-88}$ However, age is not an isolated factor accounting for these poor results.

Sarmiento et $\mathrm{al}^{85}$ found the prevalence of acetabular radiolucencies was higher in young patients who had rheumatoid arthritis or osteonecrosis (32\%) compared with older patients $(11 \%)$ with cemented total hip replacement. On the other hand, the prevalence of acetabular wear did not differ between younger and older patients who had osteoarthritis. They concluded that the quality of trabecular bone available for fixation of the component was an important factor. In osteonecrotic bone, the common histomorphometric profile is reduction of trabecular bone volume, thickness of the osteoid seams, and calcification. The framework of cancellous bone in osteonecrosis is apparently weak. Defective cancellous bone might not support the interdigitation of cement and subsequent loading. ${ }^{89}$ Therefore, the outcome of cemented total hip arthroplasty using a first-generation cementing technique was poor, and the prevalence of implant loosening 
was as high as $57 \%$, especially on the acetabular side..$^{79,81-91}$ Calder et $\mathrm{al}^{91}$ described extensive osteocyte death and an abnormal remodeling capacity in the proximal femur in osteonecrosis, and proposed that premature implant loosening may be related to the presence of abnormal cancellous bone at the implant-bone and cement-bone interfaces.

The etiology of osteonecrosis is another factor influencing the outcome of total hip replacement. Osteonecrosis encompasses a heterogeneous group of disease entities, with a spectrum of severity that makes treatment particularly challenging.

Post-traumatic osteonecrosis refers to the onset of the condition after experiencing significant trauma. Nontraumatic osteonecrosis refers to conditions unrelated to trauma, such as alcoholism, smoking, blood clotting disorders, kidney disease, connective tissue disease, and corticosteroid use. Often the condition has no known causes, and is referred to as idiopathic osteonecrosis.

The functional outcome and mortality rate of posttraumatic osteonecrosis and idiopathic osteonecrosis is usually better than alcohol-induced and steroid-induced osteonecrosis or osteonecrosis with systemic disease. ${ }^{78,90-95}$ Corticosteroids have a direct inhibitory effect on bone formation (osteoblast activity) and increase bone resorption. Patients on steroids also have a high incidence of infection, poorer quality soft tissues, and impaired wound healing. In patients with steroid-induced osteonecrosis treated with cementless total hip replacement, the reliability of bone ingrowth may be reduced.

Phillips et $\mathrm{al}^{96}$ reported a high incidence of acetabular loosening $(15 \%)$ which increased over time with steroid-induced osteonecrosis, but bone ingrowth and stable fixation were less of a problem with regards to the femoral component if there was a good initial fit. With cemented implants, the effect of corticosteroids may lead to trabecular weakness, resulting in progressive radiolucency at the bone cement interface. The prevalence of radiolucency around cemented acetabular components ranged from $16 \%$ to $50 \%$ at $44-86$ months. ${ }^{96,97-100}$

In alcohol-induced osteonecrosis, the outcome and mortality rate of total hip replacement is worse than for idiopathic osteonecrosis. ${ }^{94}$ Yuan et al ${ }^{101}$ studied 19 patients with alcohol-induced osteonecrosis (24 hips) and concluded that the continued use of alcohol was associated with a slightly increased risk of cementless implant failure $(61 \%$ implant survivorship at 10 years in those with continued alcohol intake compared with $75 \% 10$-year survivorship in those without).

Osteonecrosis of the femoral head in renal transplant patients occurs as a result of use of corticosteroids and other medications. Cemented total hip replacement ${ }^{102}$ seems to be a better option in these patients because of poor bone stock. The short-term implant survivorship was $85 \%-100 \%{ }^{103-105}$ at 3-5 years of follow-up and the long-term survivorship (free for revision) was $78 \%-100 \%$ at 10 years ${ }^{106,107}$ (Table 4).

Goffin et al ${ }^{106}$ reported a large series of 63 renal transplant patients who had $99.8 \%$ survivorship of cemented Charnley total hip replacements without loosening at a mean of 10 years. However, the survival rate dropped to $63.8 \%$ at 20 years and survival rate with death as the endpoint was $81.7 \%$ at 10 years and $35.8 \%$ at 20 years. Factors such as the type of dialysis prior to transplantation (hemodialysis versus peritoneal), persistence of post-transplant hyperparathyroidism, incidence of acute rejection episodes in the first post-transplant months (indicative of administration of higher steroid doses) appeared to affect the outcome. The incidence of aseptic loosening for cemented components was as high as $46 \%$ at 10 years. ${ }^{108}$

Renal osteodystrophy causes increased bone resorption and decreased bone formation, resulting in osteopenia. Diminished parathyroid hormone levels after transplantation, as well as accompanying steroid use, further decrease osteoblastic activity. Interestingly, the long-term results of cementless implants in transplant patients have not been reported. There are some short-term studies that demonstrate similar outcomes and survival rates between cementless and cemented implants in steroid-taking versus nonsteroid-taking age-matched patients with renal disease, but complications in the former group of patients, such as dislocation rate, are still higher $(14.8 \%$ versus $3 \%-5.8 \%$ in the nonimmunosuppressive group). ${ }^{92}$

Murzic et al ${ }^{108}$ followed 13 porous-coated cementless total hip replacements in renal transplant patients for a mean duration of 3.1 years and found that none of the hips had to be revised. They concluded that the early results of porous-coated implants were satisfactory. During the last decade, the number of short-stem arthroplasties is increasing, although there are no reports on the outcome of short-stem arthroplasties in patients with ONFH. One study reports the use of a metaphyseal-fitting anatomic cementless femoral component in 84 total hip replacements in patients with a mean age of 78.9 (range 70-88) years. The mean follow-up duration was $4.6(4-5)$ years. The mean preoperative Harris hip score was $26(0-56)$, which improved to $89(61-100)$ at the final follow-up. No patient had thigh pain. Osseointegration was seen in all femoral and acetabular components. All hips had grade 1 stress shielding of the proximal femur. No acetabular or femoral osteolysis was identified. ${ }^{109}$ 
Table 4 Evidence for the outcome of total hip replacement in post-renal transplant patients

\begin{tabular}{|c|c|c|c|c|c|}
\hline$\overline{\text { Study }}$ & Prosthesis & $\begin{array}{l}\text { Hips } \\
\text { (n) }\end{array}$ & $\begin{array}{l}\text { Mean follow-up } \\
\text { (years) }\end{array}$ & Survivorship & Causes of failure \\
\hline Alpert et $\mathrm{a}^{92}$ & $\begin{array}{l}\text { Madreporic surface femoral } \\
\text { screw ring cup } \\
\text { (cementless) }\end{array}$ & 27 & 4 & $97 \%$ (for any reason) & $\begin{array}{l}7 \% \text { fracture } \\
11 \% \text { dislocation } \\
3.7 \% \text { infection }\end{array}$ \\
\hline Bradford et al ${ }^{103}$ & $\begin{array}{l}\text { T-28 (5I) } \\
\text { Charnley (2) } \\
\text { Charnley Muller (7) } \\
\text { (cemented) }\end{array}$ & 60 & 3.4 & $\begin{array}{l}93 \% \text { (for any reason) } \\
98 \% \text { (revision free } \\
\text { for aseptic loosening) }\end{array}$ & $\begin{array}{l}2 \% \text { femoral loosening } \\
2 \% \text { infection } \\
17 \% \text { dislocation }\end{array}$ \\
\hline Chmell et al ${ }^{104}$ & Cemented & 9 & 3.6 & $100 \%$ & I I\% dislocation \\
\hline Deo et $\mathrm{a}^{105}$ & $\begin{array}{l}\text { Cemented (3I) } \\
\text { Cementless (2) } \\
\text { Hybrid (I) }\end{array}$ & 34 & 5.2 & $\begin{array}{l}85 \% \text { (revision free } \\
\text { for aseptic loosening) }\end{array}$ & $\begin{array}{l}3 \% \text { infection } \\
14.7 \% \text { loosening }\end{array}$ \\
\hline Goffin et al ${ }^{106}$ & Cemented & 93 & 18 & $\begin{array}{l}100 \% \text { at } 10 \text { years } \\
78.8 \% \text { at } 20 \text { years } \\
\text { (revision free } \\
\text { for aseptic loosening) }\end{array}$ & $\begin{array}{l}1 \% \text { dislocation } \\
2 \% \text { infection } \\
10 \% \text { aseptic loosening }\end{array}$ \\
\hline Cheng et $\mathrm{al}^{107}$ & $\begin{array}{l}\text { Cemented } \\
\text { T } 28(67) \\
\text { Muller (9) }\end{array}$ & 76 & 10 & $\begin{array}{l}91 \% \text { at } 5 \text { years } \\
78 \% \text { at } 10 \text { years } \\
\text { (revision for any reason) }\end{array}$ & $\begin{array}{l}13 \% \text { acetabular loosening } \\
13 \% \text { femoral loosening } \\
1.3 \% \text { infection } \\
16 \% \text { dislocation }\end{array}$ \\
\hline Murzic et al ${ }^{108}$ & Cemented & 32 & 8.7 & $\begin{array}{l}69 \% \text { (revision free for } \\
\text { aseptic loosening) }\end{array}$ & $\begin{array}{l}46 \% \text { loosening } \\
0 \% \text { infection }\end{array}$ \\
\hline Murzic et al ${ }^{108}$ & Cementless & 13 & 3.1 & $\begin{array}{l}100 \% \text { (revision free for } \\
\text { aseptic loosening) }\end{array}$ & $\begin{array}{l}0 \% \text { loosening for cementless } \\
10 \% \text { infection }\end{array}$ \\
\hline
\end{tabular}

Sickle cell disease has been associated with poor outcomes of total hip replacement because of high intraoperative complications, such as vaso-occlusive crises, congestive heart failure, major transfusion reaction, intraoperative femoral fracture, and perforation. Hanker et $\mathrm{al}^{110}$ performed total hip replacement in 14 sickle cell patients with a complication rate of $100 \%$, increased blood loss and transfusion requirements, and prolonged hospitalization. They recommended that the risk-benefit ratio should be carefully assessed for each individual patient. The outcome of total hip replacement was poor because of a higher rate of loosening and infection associated with functional asplenia, an abnormal immune system, and relatively poor perfusion of blood in bone secondary to sickling. Marrow hyperplasia may compromise long-term implant fixation. Marrow hyperplasia may lead to thin femoral cortices, diminution of medullary trabeculae, widening of the medullary cavity, and focal areas of sclerosis, leading to difficulties in femoral canal preparation. The survival rate of the implant was poor, with a $50 \%-60 \%$ revision rate at $3.6-9.6$ years, and early and late infection rates of $20 \%-36 \%$, respectively. ${ }^{11-113}$

Implant design and surgical technique are other important factors influencing the outcome of total hip replacement in osteonecrosis. New implant designs and bearing surfaces decrease wear and osteolysis in young active patients with osteonecrosis. ${ }^{114}$ A summary of the outcome of total hip replacement categorized by type of implant and bearing surface appears below.

\section{Cemented implants for total hip replacement}

The first-generation cement technique, initially advocated by Charnley, uses hand mixing and manual insertion with finger packing. The second-generation technique uses retrograde cement insertion with a gun, more aggressive rasping and bushing, pulsatile lavage for canal preparation, and a cement plug distally. Vacuum mixing of cement and use of proximal and distal centralizers constitutes the third-generation cementing technique. First-generation and second-generation cementing techniques in osteonecrosis had high mechanical failure rates of $9.1 \%-48 \%{ }^{78,81,84,115}$ and high revision rates of $13 \%-28 \%$ at $7-14$ years of follow-up ${ }^{78,81,115-117}$ (Table 5). The third-generation cementing technique has been shown to improve survivorship, especially on the femoral side.

Kim et al ${ }^{118}$ reported the outcome of polished tapered stems in 50 hips with osteonecrosis using the third-generation cementing technique. The survival rate was $100 \%$ at 10 years of follow-up. Similarly, Simon et a $\mathrm{l}^{119}$ reported the longevity 
Table 5 Evidence for outcome of cemented total hip replacement in osteonecrosis of the femoral head

\begin{tabular}{|c|c|c|c|c|c|}
\hline Study & $\begin{array}{l}\text { Prosthesis and cementing } \\
\text { technique }\end{array}$ & $\begin{array}{l}\text { Hips } \\
\text { (n) }\end{array}$ & $\begin{array}{l}\text { Mean follow-up } \\
\text { (years) }\end{array}$ & $\begin{array}{l}\text { Survivorship } \\
\text { (free of aseptic loosening) }\end{array}$ & Causes of failure \\
\hline Saito et $\mathrm{a}^{78}$ & $\begin{array}{l}\text { Cemented Charnley-Muller } \\
\text { (first cementing technique) }\end{array}$ & 29 & 7.2 & $72 \%$ & $\begin{array}{l}28 \% \text { aseptic loosening } \\
17 \% \text { femoral loosening } \\
7 \% \text { acetabular loosening } \\
4 \% \text { both component }\end{array}$ \\
\hline Fyda et $\mathrm{a}^{81}$ & $\begin{array}{l}\text { Charnley (29) } \\
\text { lowa (19) } \\
\text { First cementing (16) } \\
\text { Second cementing (32) }\end{array}$ & 48 & 14.5 & $87 \%$ at 10 years & $\begin{array}{l}7 \% \text { femoral loosening } \\
13 \% \text { acetabular loosening } \\
2 . \% \text { sepsis } \\
2 . \% \text { dislocation }\end{array}$ \\
\hline Kantor et $\mathrm{al}^{115}$ & Second cementing technique & 28 & 7.7 & $85.7 \%$ at 10 years & $12.5 \%$ aseptic loosening \\
\hline Katz et al ${ }^{117}$ & $\begin{array}{l}\text { Cemented (second cementing) (24) } \\
\text { Cementless (14) }\end{array}$ & 34 & 3.8 & $100 \%$ & $\begin{array}{l}3 \% \text { sepsis } \\
6 \% \text { dislocation }\end{array}$ \\
\hline Simon et al ${ }^{119}$ & $\begin{array}{l}\text { Hybrid (28) } \\
\text { Cemented (6) } \\
\text { (third cementing) } \\
\text { All polished tapered stem }\end{array}$ & 34 & 10.9 & $91 \%$ & $\begin{array}{l}15 \% \text { acetabular loosening } \\
0 \% \text { femoral loosening }\end{array}$ \\
\hline $\begin{array}{l}\text { Garino and } \\
\text { Steinberg }\end{array}$ & $\begin{array}{l}\text { Cemented (7I) } \\
\text { Hybrid (53) } \\
\text { (third cementing) }\end{array}$ & 123 & 4.6 & $97.5 \%$ & $\begin{array}{l}0.8 \% \text { infection } \\
0.8 \% \text { dislocation } \\
5 \% \text { cemented cup } \\
\text { loosening (at } 6.6 \text { years) }\end{array}$ \\
\hline Kim et al ${ }^{118}$ & $\begin{array}{l}\text { Cementless Duraloc cup } \\
\text { Cemented Elite stem }\end{array}$ & 50 & 9.3 & $100 \%$ at 10 years & $\begin{array}{l}2 \% \text { deep infection } \\
\text { No loosening }\end{array}$ \\
\hline
\end{tabular}

of polished tapered stems in 34 osteonecrotic hips and found $100 \%$ survivorship at 10 years of follow-up. However, cemented acetabular component loosening remains the main problem in young active patients. ${ }^{79,90,121}$ The failure rate of cemented acetabular components in patients with osteonecrosis is $7 \%-15 \%$ at $10-15$ years of follow-up. . $^{78,81,119}$ Using the third-generation cementing technique, the failure rate of acetabular components is still as high as $15 \%$ at 10 years of follow-up. ${ }^{120-123}$

\section{Cementless implants for total hip replacement Cementless femoral components}

Porous-coated devices were originally intended for biologic fixation by bone ingrowth for young active patients. The theoretical advantage of biologic fixation is that, once the implant has become ingrown with bone, failure at the implant-bone interface is unlikely. However, two potential problems, especially in young active patients, are stress shielding and osteolysis due to wear debris. The outcome of first-generation proximally ingrown stems such as the porouscoated anatomic implant (PCA, Howmedica Osteonics Corporation, Mahwah, NJ) and the Harris-Galante I (HG-I, Zimmer Corporation, Warsaw, IN) was unfavorable.

Kim et a ${ }^{124}$ found a high incidence of failure of the PCA (21\%) and HG-I (19\%) components at 7.5 years of follow-up in patients with osteonecrosis. Long-term survivorship of HG-I components reported by Kim et al ${ }^{125}$ was $80 \%$ at 12.5 years. The HG-I has a noncircumferential proximal porous coating that facilitates distal wear particle migration and osteolysis. Second-generation proximal porous-coated implants have been developed to improve stem canal fill in both the coronal and sagittal planes. The circumferential porous coating on the proximal one third of the stem provides more reliable ingrowth and limits distal osteolysis. Examples of second-generation proximal-coated femoral components include the anatomic profile stem (DePuy, Warsaw, IN) and anatomic hip (Zimmer Corporation).

Kim et al $^{121}$ reported the long-term outcome of the anatomic profile stem in young patients less than 50 years (66\% with osteonecrosis) and found the survivorship was $96 \%$ at 18 years of follow-up. Ha et al ${ }^{126}$ reported that the survivorship of the hydroxyapatite-coated anatomic profile stem in 46 osteonecrosis hips was $93.3 \%$ at 13 years. Hartley et $\mathrm{al}^{127}$ reported on 48 anatomic medullary locking (AML, DePuy) stems with extensive porous coating in patients with osteonecrosis using several cementless cup designs and found no femoral revisions at 10 years of follow-up. Piston et al ${ }^{128}$ reported that the survivorship of 35 AML stems was 97\% at 7.5 years of follow-up (only one patient has been revised for a loosening stem). In conclusion, second-generation proximal porous coating and extensive porous-coated stems have shown a successful long-term outcome in patients with osteonecrosis. 


\section{Cementless acetabular components}

The revision rate for cemented components is usually higher on the acetabular side than on the femoral side in osteonecrosis. Second-generation or third-generation cementing techniques have not improved implant longevity. Therefore, the cementless acetabular implant was developed to provide long-term fixation. ${ }^{129}$ The early design of porous-coated acetabular components included the PCA (chromium-cobalt beads, peg fixation), HG-I (titanium mesh optional screw fixation), and the AML (chromiumcobalt beads, spike fixation). The outcome of HGP-I and PCA cups in osteonecrosis was unsatisfactory. HGP-I had a high prevalence of failure of up to $15 \%$ at mean follow-up of 6.5-12.5 years ${ }^{124,125,130}$ because of dissociation of the polyethylene liner with breakage of the locking mechanism. The PCA cup had a high failure rate in osteonecrosis similar to that of the HG-I. The failure rate of the PCA cup was $11 \%-24 \%$ at 8-10 years of follow-up ${ }^{124,131}$ because of a poor polyethylene locking mechanism, polyethylene wear, acetabular osteolysis, and cup migration. Second-generation cups were developed to improve the outcome and survival rate.

Kim et $\mathrm{al}^{118}$ reported on the second-generation (rim locking design) Duraloc (DePuy) in 78 osteonecrotic hips and found no loosening at 9.4 years of follow-up. The longterm outcome of the Duraloc cup in patients younger than 50 years reported by Kim et al ${ }^{121}$ was an $18 \%$ failure rate at 18 years due to wear and osteolysis (66\% of patients in this group had osteonecrosis).

In conclusion, cementless cups need adequate primary stability to achieve osseointegration, and modern cups appear to achieve this goal. However, polyethylene wear and osteolysis remain matters of concern in this group of active patients. Highly cross-linked polyethylene and other newer alternative bearings, such as ceramic and metal-on-metal articulation, may reduce wear and improve the outcome of cementless cups.

\section{Wear and osteolysis in patients with osteonecrosis}

Conventional polyethylene wear limits survivorship of total hip replacement in young active patients. Particle-induced periprosthetic osteolysis and aseptic loosening are major complications. The average wear rate of conventional polyethylene has been estimated to be $0.10 \mathrm{~mm}$ per year in osteoarthritis. ${ }^{132,133}$ In young active patients with osteonecrosis, the annual wear rate has been reported to be $0.03-0.18 \mathrm{~mm} . .^{96,124,126}$ The prevalence of osteolysis with cementless implants ranges from $11 \%-80 \%$ on the femoral side and $7.6 \%-36 \%$ on the acetabular side at 7-18 years of follow-up (see Table 6). Factors that correlate with osteolysis are polyethylene wear rate, duration of implantation, and implant design. The prevalence of osteolysis for cementless implants (HG-I, PCA, Profile) in young osteonecrosis patients (aged $31-53$ years) was $7.6 \%-80 \%$ and the linear wear rate was $0.14-0.21 \mathrm{~mm}$ per year. This is not different from patients with osteoarthritis of the same age.

Hallan et $\mathrm{al}^{134}$ reported wear rates for HG-I, PCA, and Profile components in 96 primary and secondary osteoarthritis at 12-16 years of follow-up. They found the same range of wear rate of $0.17-0.21 \mathrm{~mm}$ per year, and the prevalence of osteolysis was $48 \%-64 \%$ depending on the type of implant. Newer cementless implant designs that improve canal fit may help to decrease the rate of osteolysis. ${ }^{110}$ However, the wear rate of conventional polyethylene bearing surfaces is still high in young active patients. New polyethylenes and

Table 6 Prevalence of osteolysis and wear rate with conventional polyethylene in osteonecrosis

\begin{tabular}{|c|c|c|c|c|c|c|c|}
\hline Study & Implant design & Hips (n) & $\begin{array}{l}\text { Mean age } \\
\text { (years) }\end{array}$ & $\begin{array}{l}\text { Mean follow-up } \\
\text { (years) }\end{array}$ & $\begin{array}{l}\text { Linear wear rate } \\
\text { (mm/year) }\end{array}$ & $\begin{array}{l}\text { Femoral } \\
\text { osteolysis } \\
(\%)\end{array}$ & $\begin{array}{l}\text { Acetabular } \\
\text { osteolysis } \\
\text { (\%) }\end{array}$ \\
\hline Kim et al ${ }^{125}$ & HGP-I & 65 & 53 & 12.5 & 0.14 & 29 & 7.6 \\
\hline \multirow[t]{4}{*}{ Kim et al ${ }^{121, *}$} & Duraloc cup and & 109 & 43 & 18 & 0.21 & 28 & 32 \\
\hline & Elite (plus) or & (hybrid) & 47 & 18 & 0.21 & 22 & 36 \\
\hline & Profile stem & 110 & & & & & \\
\hline & & (cementless) & & & & & \\
\hline Ha et $\mathrm{al}^{126}$ & $\begin{array}{l}\text { Profile hydroxyapatite } \\
\text { stem }\end{array}$ & 36 & 48.6 & 10 & 0.18 & 80 & 30 \\
\hline Piston et al $\left.\right|^{128}$ & AML & 35 & 32 & 7.5 & NA & 11 & 17 \\
\hline \multirow[t]{2}{*}{ Hartley et al ${ }^{127}$} & AML & 38 & 31 & 9.4 & NA & 21 & 16 \\
\hline & Prodigy & & & & & & \\
\hline
\end{tabular}

Notes: *Study in young patients. Approximately $66 \%$ in each group were osteonecrosis patients.

Abbreviations: AML, anatomic medullary locking; NA, not available. 
hard-on-hard bearing surfaces are strategies to decrease the wear rate in this group of patients.

\section{Highly cross-linked polyethylene}

The use of high cross-linked polyethylene (HXPE) in total hip arthroplasty has become more popular because of a reduced linear wear rate of up to $40 \%$ compared with conventional polyethylene. ${ }^{135-137} \mathrm{HXPE}$ in patients young than 60 years yielded mean wear rates for $0.02-0.04 \mathrm{~mm}$ per year, significantly less than conventional polyethylene, with no cases of osteolysis (Table 7). Only one study has published results for HXPE in patients with osteonecrosis.

Mont et $\mathrm{al}^{138}$ found no prevalence of osteolysis using the Crossfire HXPE in 81 osteonecrotic hips at 4 years of follow-up. We recently reviewed the outcome for 66 patients with osteonecrosis of the hip requiring total hip replacement, and use of HXPE after a mean of 4 years of follow-up yielded a linear wear rate of $0.07 \mathrm{~mm}$ per year with no evidence of osteolysis. However, the wear rate in this study may be slightly more than in other studies because of a younger patient age. In conclusion, the short-term to mid-term outcome of HXPE in young patients is excellent. However, the long-term outcome of total hip replacement with HXPE is unknown.

\section{Metal-on-metal bearing surface}

The rationale for use of metal-on metal articulations is that it produces less volumetric wear than metal-on-polyethylene and may result in a decreased incidence of osteolysis, particularly in young active patients. ${ }^{139,140}$ First-generation metal-on-metal McKee-Farrar total hip replacements have been abandoned because of suboptimal implant design, inconsistent manufacturing tolerances, and poor surgical technique. In the 1990s, second-generation metal-on metal Metasul (Zimmer Corporation) hip prostheses were introduced with improved materials, design, and better quality control during manufacturing.

Dastane et $\mathrm{al}^{141}$ reported the clinical and radiographic results of Metasul implants in patients with osteonecrosis or osteoarthritis at 5 years of follow-up. They found no significant differences and no evidence of osteolysis. Sieber et $\mathrm{al}^{142}$ reported volumetric wear after the run-in period to be $0.3 \mathrm{~mm}^{3}$ per year, which is 60 times less than with metalon-conventional polyethylene articulations. The prevalence of osteolysis in young patients with metal-on-metal implants has ranged from zero to $6 \%$ (Table 8 ). The survivorship of metal-on-metal in young active patients was $94.5 \%-100 \%$ at 5-10 years of follow-up.

However, many studies have reported early osteolysis following second-generation metal-on-metal implants. Kim et $\mathrm{al}^{143}$ found that $2.8 \%$ of Metasul-bearing surfaces had osteolysis, and histologic examination of pelvic osteolytic lesions showed multiple lymphocytes with a perivascular distribution and a small number of macrophages. This suggests that the cause of the osteolysis was a metal-associated hypersensitivity reaction with vasculitis rather than a simple foreign body reaction. Park et $\mathrm{al}^{144}$ reported early osteolysis

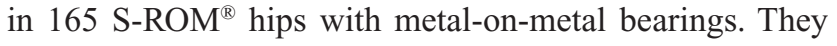
found osteolysis in $6 \%$ of cases at 24 months, with a similar histologic picture as described above. Neither particle-laden

Table 7 Evidence for osteolysis and wear rates of highly cross-linked polyethylene in osteonecrosis patients

\begin{tabular}{|c|c|c|c|c|c|c|c|}
\hline Study & $\begin{array}{l}\text { Bearing } \\
\text { surface }\end{array}$ & $\begin{array}{l}\text { Mean age } \\
\text { (years) }\end{array}$ & $\begin{array}{l}\text { Mean follow-up } \\
\text { (years) }\end{array}$ & $\begin{array}{l}\text { Survivorship } \\
\text { (free of loosening) }\end{array}$ & $\begin{array}{l}\text { Mean linear } \\
\text { wear rate } \\
\text { (mm/year) }\end{array}$ & $\begin{array}{l}\text { Mean volumetric } \\
\text { wear rate } \\
\left(\mathrm{mm}^{3} / \text { year) }\right.\end{array}$ & Osteolysis \\
\hline Mont et $\mathrm{al}^{138}$ & $\begin{array}{l}\text { Crossfire } \\
\text { (8I hips) } \\
\text { Trident } \\
\text { (23 hips) }\end{array}$ & 38 & 4 & $99 \%$ at 4 yrs & NA & NA & $0 \%$ \\
\hline Lachiewicz et al $^{145, *}$ & $\begin{array}{l}\text { Longevity } \\
\text { (102 hips) } \\
\text { (20\% ON) }\end{array}$ & 61 & 5.7 & NA & 0.04 & 80.5 & $0 \%$ \\
\hline Dorr et al ${ }^{136, *}$ & $\begin{array}{l}\text { Durasul } \\
\text { (37 hips) } \\
(16 \% \text { ON) }\end{array}$ & 60 & 5 & NA & 0.02 & NA & $0 \%$ \\
\hline Bitsch et $a^{146, *}$ & $\begin{array}{l}\text { Marathon } \\
\text { (32 hips) }\end{array}$ & 60 & 5.8 & NA & 0.03 & 15.4 & $0 \%$ \\
\hline $\begin{array}{l}\text { Waewsawangwong } \\
\text { et al** }\end{array}$ & $\begin{array}{l}\text { Longevity } \\
\text { (66 hips) }\end{array}$ & 48 & 4 & $\begin{array}{l}100 \% \text { at } \\
4 \text { years }\end{array}$ & 0.07 & NA & $0 \%$ \\
\hline
\end{tabular}

Notes: *Study in young patients; **unpublished data.

Abbreviations: ON, osteonecrosis; NA, not available. 
Table 8 Evidence for prevalence of osteolysis and survival rate for metal-on-metal total hip replacement

\begin{tabular}{|c|c|c|c|c|c|c|}
\hline Study & Implant & Hips (n) & $\begin{array}{l}\text { Mean age } \\
\text { (years) }\end{array}$ & $\begin{array}{l}\text { Mean follow-up } \\
\text { (year) }\end{array}$ & $\begin{array}{l}\text { Survival rate } \\
\text { (\%) }\end{array}$ & $\begin{array}{l}\text { Osteolysis } \\
\text { (\%) }\end{array}$ \\
\hline Dastane et $\mathrm{al}^{141}$ & $\begin{array}{l}\text { Metasul } \\
\text { (multicup design mated } \\
\text { with APR stem) }\end{array}$ & 30 & 44.7 & 5.5 & $100 \%$ at 5 years & $0 \%$ \\
\hline Girard et al $\left.\right|^{147}$ & $\begin{array}{l}\text { Metasul } \\
\text { Armor/Allofit cup } \\
\text { Zweymuller SL stem/ } \\
\text { Muller cemented stem }\end{array}$ & 47 (ON 54\%) & 25 & 9 & $94.5 \%$ at 10 years* & $\begin{array}{l}6 \% \text { on femur } \\
4 \% \text { on pelvis }\end{array}$ \\
\hline Kim et al ${ }^{143}$ & $\begin{array}{l}\text { CLS } \\
\text { Metasul bearing }\end{array}$ & 68 (ON 87\%) & 37 & 7 & $100 \%$ at 7 years & $\begin{array}{l}\mathrm{I} .4 \% \text { on femur } \\
\mathrm{I} .4 \% \text { on pelvis }\end{array}$ \\
\hline Park et al ${ }^{144}$ & S-ROM (DePuy) & I 65 (ON 54\%) & 56.7 & 2.3 & $98.8 \%$ at 2 years & $6 \%$ on femur \\
\hline
\end{tabular}

Note: *No significant differences in survival rate with different preoperative diagnoses.

Abbreviation: $\mathrm{ON}$, osteonecrosis.

macrophages nor polymorphonuclear leukocytes were seen. Antigen-specific sensitization of T cells (delayed-type hypersensitivity) may play a role in the development of early osteolysis following second-generation metal-on-metal total hip replacement. Moreover, metal-on-metal implants generate smaller wear particles and ions with systemic distribution that have to be monitored closely. Regarding the generation of metal ions seen in the blood and urine of patients with metalon-metal implants, these elevated metal ions have theoretical although not proven risks related to hypersensitivity and carcinogenesis as well as other biologic concerns. There are also concerns regarding increased costs. ${ }^{148}$

\section{Ceramic-on-ceramic bearing surface}

Alumina or zirconia heads have both increased hardness and strength, which reduces abrasive wear by up to $50 \%$ compared with metal-on-polyethylene bearings, and may reduce the prevalence of osteolysis. ${ }^{149,150}$ Early prostheses had high failure rates as a result of poor acetabular fixation, implant fracture, and sporadic excessive wear of the bearing surface.

Hamadouche et al ${ }^{151}$ reported a 61.2\% 20-year survival rate for cemented cups in a long-term review of 118 aluminum total hip replacements. Third-generation ceramic implants were introduced in 1994. These improvements include decreased ceramic grain size, higher density, lower porosity as a result of hot isostatic pressing, laser etching, nondestructive proof-testing, and a metal-backed socket for acetabular fixation. ${ }^{152-157}$

The survivorship of ceramic-on-ceramic implants in patients with osteonecrosis varied between $85 \%$ and $100 \%$ at $10-15$ years of follow-up depending on implant design. No osteolysis has been reported. However, complications after ceramic-on-ceramic implants in high-demand young active patients are not uncommon. In patients with osteonecrosis, clicking or squeaking occurs in $2 \%-20 \%,{ }^{158,159}$ dislocation in $2 \%-4 \%,{ }^{158,160}$ intraoperative ceramic insert chipping in

Table 9 Evidence for survival rate and prevalence of osteolysis in ceramic-on-ceramic implants

\begin{tabular}{|c|c|c|c|c|c|c|}
\hline Study & Implant & $\begin{array}{l}\text { Hips } \\
\text { (n) }\end{array}$ & Age (years) & $\begin{array}{l}\text { Follow-up } \\
\text { (years) }\end{array}$ & Survival rate (revision) & Osteolysis \\
\hline \multirow[t]{5}{*}{ Bizot et al ${ }^{156}$} & 4 type socket & & $32.3(17-40)$ & $2-22$ & Socket type & \\
\hline & I. Cemented alumina & 41 & & & $90.4 \%$ at 10 years & 0 \\
\hline & 2. Screw in ring with aluminum insert & 22 & & & $88.8 \%$ at 10 years & \\
\hline & 3. Press fit plain aluminum socket & 32 & & & $95.1 \%$ at 7 years & \\
\hline & 4. Metal back aluminum insert & 33 & & & $94.3 \%$ at 7 years & \\
\hline \multirow[t]{2}{*}{ Nich et al ${ }^{160}$} & Cemented cup at first 39 cups & 52 & $4 \mathrm{I}(22-79)$ & 16 & $84.5 \%$ at 10 years & 0 \\
\hline & Press fit aluminum cup (later I 3 cups) & & & & $65 \%$ at 16 years & \\
\hline Seyler et $\mathrm{al}^{161}$ & ABC I, ABC II, Trident & 79 & $45.2(21-67)$ & $4.2(0.7-7.7)$ & $95.5 \%$ & 0 \\
\hline \multirow[t]{3}{*}{ Kim et al ${ }^{158, *}$} & IPS femoral component & 93 & $38.2(24-45)$ & $11.1(10-13)$ & Acetabular $99 \%$ at 10 years & 0 \\
\hline & Duraloc cup & & & & Femoral $100 \%$ at 10 years & \\
\hline & Biolox forte (bearing) & & & & & \\
\hline \multirow[t]{3}{*}{ Baek and $\mathrm{Kim}^{159}$} & Biolox forte bearing & 71 & 39.1 & 7.1 & $100 \%$ at 6 years & 0 \\
\hline & Plasmacup & & & & & \\
\hline & BiContact (Aesculap) & & & & & \\
\hline
\end{tabular}

Note: *Study in young patients (55\% of patients in this group had osteonecrosis). 
$1 \%-2.6 \%,{ }^{161,162}$ and intraoperative fracture of the femur in $2.8 \%-5.7 \%{ }^{159,160}$ (Table 9). Methods to prevent these complications include obtaining optimal implant position, absence of a trochanteric osteotomy, efforts to preserve and reconstruct soft tissues, and restoration of limb length.

In conclusion, ceramic-on-ceramic bearing surfaces have an advantage over metal-on-metal bearing surfaces in this patient population because of their chemical inertness. However, ceramic-on-ceramic bearings have issues of concern, such as cup fixation, femoral head or acetabular component breakage or chipping, and squeaking, especially in young active patients.

\section{Summary}

Treatment of advanced post-collapse ONFH is challenging and controversial. Patient selection is very important. Limited resurfacing and total resurfacing may be options for young patients with limited involvement of the femoral head. However, unexpected failure, including further osteonecrosis, femoral neck fractures, and in the case of hemiresurfacing, acetabular cartilage degeneration, is of concern. Total hip replacement may be more appropriate for older patients with extensive femoral head and acetabular involvement. The use of new bearing surfaces, such as HXPE, metal-on-metal, and ceramic-on-ceramic, have been reported to improve the longevity of implants. However, each of these new bearing surfaces has potential advantages and shortcomings that will become more apparent with longer follow-up.

\section{Disclosure}

The authors report no conflicts of interest in this work.

\section{References}

1. Lavernia CJ, Sierra RJ, Grieco FR. Osteonecrosis of the femoral head. J Am Acad Orthop Surg. 1999;7:250-261.

2. Vail TP, Covington DB. The incidence of osteonecrosis. In: Urbaniak JR, Jones JR, editors. Osteonecrosis: Etiology, Diagnosis, Treatment. Rosemont, IL: American Academy of Orthopedic Surgeons; 1997.

3. Mont MA, Zywiel MG, Marker DR, McGrath MS, Delanois RE. The natural history of untreated asymptomatic osteonecrosis of the femoral head: a systematic literature review. J Bone Joint Surg Am. 2010;92:2165-2170.

4. Hungerford DS. Treatment of avascular necrosis in the young patient. Orthopedics. 1995;18:822-823.

5. Smith SW, Fehring TK, Griffin WL, Beaver WB. Core decompression of the osteonecrotic femoral head. J Bone Joint Surg Am. 1995;77:674-680.

6. Bozic KJ, Zurakowski D, Thornhill TS. Survivorship analysis of hips treated with core decompression for nontraumatic osteonecrosis of the femoral head. J Bone Joint Surg Am. 1999;81:200-209.

7. Ficat RP, Arlet J. Necrosis of the femoral head. In: Hungerford DS, editors. Ischemia and Necrosis of Bone. Baltimore, MD: Williams \& Wilkins; 1980.
8. Mont MA, Einhorn TA, Sponseller PD, Hungerford DS. The trapdoor procedure using autogenous cortical and cancellous bone grafts for osteonecrosis of the femoral head. J Bone Joint Surg Br. 1998;80:56-62.

9. Ko JY, Meyers MH, Wenger DR. "Trapdoor" procedure for osteonecrosis with segmental collapse of the femoral head in teenagers. J Pediatr Orthop. 1995;15:7-15.

10. Berend KR, Gunneson EE, Urbaniak JR. Free vascularized fibular grafting for the treatment of postcollapse osteonecrosis of the femoral head. J Bone Joint Surg Am. 2003;85:987-993.

11. Scher MA, Jakim I. Intertrochanteric osteotomy and autogenous bonegrafting for avascular necrosis of the femoral head. J Bone Joint Surg Am. 1993;75:1119-1133.

12. Freiherr von Salis-Soglio G, Ruff C. Idiopathic femur head necrosis in the adult - results of surgical therapy. Z Orthop Ihre Grenzgeb. 1988;126:492-499.

13. Tooke SMT, Amstutz HC, Hedley AK. Results of transtrochanteric rotational osteotomy for femoral head osteonecrosis. Clin Orthop. 1987;224:150-157.

14. Grigoris P, Safran M, Brown I, Amstutz HC. Long-term results of transtrochanteric rotational osteotomy for femoral head osteonecrosis. Arch Orthop Trauma Surg. 1996;115:127-130.

15. Masuda T, Matsuno T, Hasegawa I. Results of transtrochanteric rotational osteotomy for nontraumatic osteonecrosis of the femoral head. Clin Orthop Relat Res. 1988;228:69-74.

16. Drescher W, Fürst M, Hahne HJ. Flexion osteotomy of femoral head necrosis. J Bone Joint Surg Br. 2003;85:969-974.

17. Schneider W, Aigner N, Pinggera O. Intertrochanteric osteotomy for avascular necrosis of the head of the femur. Survival probability of two different methods. J Bone Joint Surg Br. 2002;84:817-824.

18. Inao S, Ando M, Gotoh E. Minimum 10-year results of Sugioka's osteotomy for femoral head osteonecrosis. Clin Orthop Relat Res. 1999;368:141-148.

19. de Meulemeester FR, Rozing PM. Uncemented surface replacement for osteonecrosis of the femoral head - management of Ficat Stage III and IV Osteonecrosis of the Hip. Acta Orthop Scand. 1989;60:425-429.

20. Nelson CL, Walz BH, Gruenwald JM. Resurfacing of only the femoral head for osteonecrosis: long-term follow-up study. $J$ Arthroplasty. 1997; 12:736-740.

21. Scott RD, Urse JS, Schmidt R. Use of TARA hemiarthroplasty in advanced osteonecrosis. J Arthroplasty. 1987;2:225-232.

22. Amstutz HC, Grigoris P, Safran MR. Precision-fit surface hemiarthroplasty for femoral head osteonecrosis: long-term results. J Bone Joint Surg Br. 1994;76:423-427.

23. Hungerford MW, Mont MA, Scott R. Surface replacement hemiarthroplasty for the treatment of osteonecrosis of the femoral head. J Bone Joint Surg Am. 1998;80:1656-1664.

24. Seyler TM, Cui Q, Mihalko WM. Advance in hip arthroplasty in the treatment of the femoral head. Instr Course Lect. 2007;56:221-233.

25. Nelson CL, Walz BH, Gruenwald JM. Resurfacing of only the femoral head for osteonecrosis. Long-term follow-up study. J Arthroplasty. 1997; 12:736-740

26. Mont MA, Rajadhyaksha AD, Hungerford DS. Outcomes of limited femoral resurfacing arthroplasty compared with total hip arthroplasty for osteonecrosis of the femoral head. J Arthroplasty. 2001;16(8 Suppl 1): 134-139.

27. Beaule PE, Schmalzried TP, Campbell P. Symptoms and outcome of hemi-resurfacing for hip osteonecrosis. Clin Orthop Relat Res. 2001;385:104-117.

28. Krackow KA, Mont MA, Maar DC. Limited femoral end prosthesis for avascular necrosis of femoral head. Orthop Rev. 1993;22: 457-463.

29. Sedel L, Travers V, Witvoet J. Spherocylindric (Luck) cup arthroplasty for osteonecrosis of the hip. Clin Orthop. 1987;219:127-135.

30. Squire M, Fehring TK, Odum S. Failure of femoral surface replacement for femoral head avascular necrosis. J Arthroplasty. 2005;20(7 Suppl 3): $108-114$. 
31. Cuckler JM, Moore KD, Estrada L. Outcome of hemiresurfacing in osteonecrosis of the femoral head. Clin Orthop Relat Res. 2004:429:146-150.

32. Adili A, Trousdale RT. Femoral head resurfacing for the treatment of osteonecrosis in the young patient. Clin Orthop Relat Res. 2003;417:93-101

33. Daniel J, McBryde C, Pradhan C, Ziaee H. Results of Birmingham hip resurfacing in different diagnoses. In: McMinn D, editor. Modern Hip Resurfacing. London, UK: Springer; 2009.

34. Ash SA, Callaghan JJ, Johnston RC. Revision total hip arthroplasty with cement after cup arthroplasty: long-term follow-up. J Bone Joint Surg Am. 1996;78:87-93.

35. Siguier T, Siguier M, Judet T. Partial resurfacing arthroplasty of the femoral head in avascular necrosis methods, indications, and results. Clin Orthop Relat Res. 2001;386:85-92.

36. Yamagata M, Chao EY, Ilstrup DM. Fixed-head and bipolar hip endoprostheses. A retrospective clinical and roentgenographic study. $J$ Arthroplasty. 1987;2:327-341.

37. Bateman JE. Single assembly total hip prosthesis: preliminary report. 1974. Clin Orthop Relat Res. 1990;251:3-6.

38. Giliberty RP. A new concept of a bipolar endoprosthesis. Orthop Rev. 1974;3:40-45

39. Cabanela ME. Bipolar versus total hip arthroplasty for avascular necrosis of the femoral head: a comparison. Clin Orthop. 1990;261:59-62.

40. Pellegrini VD Jr, Heiges BA, Bixler B. Minimum ten-year results of primary bipolar hip arthroplasty for degenerative arthritis of the hip. J Bone Joint Surg Am. 2006;88:1817-1825.

41. Takaoka K, Nishina T, Ohzono K, et al. Bipolar prosthetic replacement for the treatment of avascular necrosis of the femoral head. Clin Orthop. 1992;277:121-127.

42. Bateman JE, Berenji AR, Bayne O, Greyson ND. Long-term results of bipolar arthroplasty in osteoarthritis of the hip. Clin Orthop. 1990; 251:54-66.

43. Kindsfater KA, Spitzer AI, Schaffer JL, Scott RD. Bipolar hemiarthroplasty for primary osteoarthritis of the hip: a review of 41 cases with 8 to 10 years of follow-up. Orthopedics. 1998;21: 425-431.

44. Nagai I, Takatori Y, Kuruta Y, et al. Nonself-centering Bateman bipolar endoprosthesis for nontraumatic osteonecrosis of the femoral head: a 12- to 18-year follow-up study. J Orthop Sci. 2002;7:74-78.

45. Lee SB, Sugano N, Nakata K, Matsui M, Ohzono K. Comparison between bipolar hemiarthroplasty and THA for osteonecrosis of the femoral head. Clin Orthop Relat Res. 2004;424:161-165.

46. Chan YS, Shih CH. Bipolar versus total hip arthroplasty for hip osteonecrosis in the same patient. Clin Orthop Relat Res. 2000;379: 169-177.

47. Meijerink HJ, Gardeniers JW, Buma P, Lemmens JA, Schreurs BW. Hydroxyapatite does not improve the outcome of a bipolar hemiarthroplasty. Clin Orthop Relat Res. 2004;421:143-150.

48. Ito H, Matsuno T, Kaneda K. Hemiarthroplasty for osteonecrosis of the femoral head a 7- to 18-year follow up. Clin Orthop Relat Res. 2000;374:201-211.

49. Murzic WJ, McCollum DE. Hip arthroplasty for osteonecrosis after renal transplantation. Clin Orthop Relat Res. 1994;299:212-219.

50. Pankaj A, Malhotra R, Bhan S. Conversion of failed hemiarthroplasty to total hip arthroplasty: a short to mid-term follow-up study. Indian J Orthop. 2008;42:294-300.

51. Lachiewicz PF, Desman SM. The bipolar endoprosthesis in avascular necrosis of the femoral head. J Arthroplasty. 1988;3:131-138.

52. Kim KJ, Rubash HE. Large amounts of polyethylene debris in the interface tissue surrounding bipolar endoprostheses: comparison to total hip prostheses. J Arthroplasty. 1997;12:32-39.

53. Yamano K,Atsumi T, Kajwara T. Bipolar endoprosthesis for osteonecrosis of femoral head: a 12-year follow up of 29 hips. ARCO Transactions. 2004.

54. Shimmin A, Beaulé PE, Campbell P. Metal-on-metal hip resurfacing arthroplasty. J Bone Joint Surg Am. 2008;90:637-654.

55. Grecula MJ, Grigoris P, Schmalzried TP. Endoprostheses for osteonecrosis of the femoral head. A comparison of four models in young patients. Int Orthop. 1995;19:137-143.
56. Smith SL, Dowson D, Goldsmith AAJ. The effect of femoral head diameter upon lubrication and wear of metal-on-metal total hip replacements. Proc Inst Mech Eng H. 2001;215:161-170.

57. Langton DJ, Jameson SS, Joyce TJ, Webb J, Nargol AVF. The effect of component size and orientations of metal ions after resurfacing of the hip. J Bone Joint Surg Br. 2008;90-B:1143-1151.

58. Australian Orthopaedic Association. National Joint Replacement Registry Annual Report. Adelaide, Australia: Australian Orthopaedic Association; 2007.

59. Beaule PE, Amstutz HC, Le Duff M, Dorey F. Surface arthroplasty for osteonecrosis of the hip: hemiresurfacing versus metal-on-metal hybrid resurfacing. J Arthroplasty. 2004;19(8 Suppl 3):54-58.

60. Seyler TM, Marker DR, Boyd HS, Zywiel MG, McGrath MS, Mont MA. Preoperative evaluation to determine candidates for metalon-metal hip resurfacing. J Bone Joint Surg Am. 2009;91:32-41.

61. Revell MP, McBryde CW, Bhatnagar S, Pynsent PB, Treacy RB. Metal-on-metal hip resurfacing in osteonecrosis of the femoral head. J Bone Joint Surg Am. 2006;88 Suppl 3:98-103.

62. Mont MA, Seyler TM, Marker DR, Marulanda GA, Delanois RE. Use of metal-on-metal total hip resurfacing for the treatment of osteonecrosis of the femoral head. J Bone Joint Surg Am. 2006;88:90-97.

63. Sayeed SA, Johnson AJ, Stroh DA, Gross TP, Mont MA. Hip resurfacing in patients who have osteonecrosis and are 25 years or under. Clin Orthop Relat Res. 2011;469:1582-1588.

64. Aulakh TS, Rao C, Kuiper JH, Richardson JB. Hip resurfacing and osteonecrosis: results from an independent hip resurfacing register. Arch Orthop Trauma Surg. 2010;130:841-845.

65. Australian Orthopaedic Association. National Joint Replacement Registry Annual Report. Adelaide, Australia: Australian Orthopaedic Association; 2005.

66. Steffen RT, Smith SR, Urban JP, et al. The effect of hip resurfacing on oxygen concentration in the femoral head. J Bone Joint Surg Br. 2005;87:1468-1474.

67. Little CP, Ruiz AL, Harding IJ, et al. Osteonecrosis in retrieved femoral heads after failed resurfacing arthroplasty of the hip. J Bone Joint Surg Br. 2005;87:320-323.

68. Steffen RT, Athanasou NA, Gill HS, Murray DW. Avascular necrosis associated with fracture of the femoral neck after hip resurfacing: histological assessment of femoral bone from retrieval specimens. J Bone Joint Surg Br. 2010;92-B:787-793.

69. McMinn DJ, Daniel J, Pradhan C, Ziaee H. Avascular necrosis in the young patient: a trilogy of arthroplasty options. Orthopedics. 2005;2: 945-947.

70. Khan A, Yates P, Lovering A, Bannister GC, Spencer RF. The effect of surgical approach on blood flow to the femoral head during resurfacing. J Bone Joint Surg Br. 2007;89-B:21-25.

71. Amarasekera HW, Costa ML, Foguet P. The blood flow to the femoral head/neck junction during resurfacing arthroplasty: a comparison of two approaches using laser Doppler flowmetry. J Bone Joint Surg Br. 2008;90-B:442-425.

72. Campbell P, Mira J, Amstutz HC. Viability of femoral heads treated with resurfacing arthroplasty. J Arthroplasty. 2000;15:120-122.

73. Ganz R, Gill TJ, Gautier E, Ganz K, Krügel N, Berlemann U. Surgical dislocation of the adult hip a technique with full access to the femoral head and acetabulum without the risk of avascular necrosis. $J$ Bone Joint Surg Br. 2001;83:1119-1124.

74. Beaulé PE, Campbell P, Shim P. Femoral head blood flow during hip resurfacing. Clin Orthop Relat Res. 2007;456:148-152.

75. Campbell P, Beaulé PE, Ebramzadeh E, et al. A study of implant failure in metal-on-metal surface arthroplasties. Clin Orthop Relat Res. 2006;453:35-46.

76. Ortiguera CJ, Pulliam IT, Cabanela ME. Total hip arthroplasty for osteonecrosis: matched-pair analysis of 188 hips with long-term followup. J Arthroplasty. 1999;14:21-28.

77. Salvati EA, Cornell CN. Long-term follow-up of total hip replacements in patients with avascular necrosis. Inst Course Lect. 1988;37: $67-73$. 
78. Saito S, Saito M, Nishina T, Ohzono K. Long term result of total hip arthroplasty for osteonecrosis of the femoral head: a comparison with osteoarthritis. Clin Orthop Relat Res. 1989;3:131-138.

79. Chandler HP, Reinneck FT, Wixson RL, McCarthy JC. Total hip replacement in patients younger than thirty years old: a five year follow up study. J Bone Joint Surg Am. 1981;63:1426-1434.

80. Katz RL, Bourne RB, Rorabeck CH, McGee H. Total hip arthroplasty in patients with avascular necrosis of the hip. Follow-up observations on cementless and cemented operations. Clin Orthop. 1992;281: $145-151$.

81. Fyda TM, Callaghan JJ, Olejniczak J, Johnston RC. Minimum ten-year follow-up of cemented total hip replacement in patients with osteonecrosis of the femoral head. Iowa Orthop J. 2002;22:8-19.

82. Boettcher WG, Bonfiglio M, Hamilton HH, Sheets RF, Smith K. Non-traumatic necrosis of the femoral head. Part I. Relation of altered hemostasis to etiology. J Bone Joint Surg Am. 1970;52:312-321.

83. Boettcher WG, Bonfiglio M, Hamilton HH, Sheets RF, Smith K. Non-traumatic necrosis of the femoral head. Part II. Experiences in treatment. J Bone Joint Surg Am. 1970;52-A:322-329.

84. Cornell CN, Salvati EA, Pellicci PM. Long-term follow-up of total hip replacement in patients with osteonecrosis. Orthop Clin North Am. 1985;16:757-769.

85. Sarmiento A, Ebramzadeh E, Gogan WJ, McKellop HA. Total hip arthroplasty with cement. A long-term radiographic analysis in patients who are older than fifty and younger than fifty years. J Bone Joint Surg Am. 1990;72-A:1470-1476.

86. Dorr LD, Kane TJ 3rd, Conaty JP. Long term results of cemented total hip arthroplasty in patients 45 years old or younger. A 16-year follow-up study. J Arthroplasty. 1994;9:453-456.

87. Dorr LD, Takei GK, Conaty JP. Total hip arthroplasties in patients less than forty-five years old. J Bone Joint Surg Am. 1983;65-A(4): 474-479.

88. Stulberg BN, Singer R, Goldner J, Stulberg J. Uncemented total hip arthroplasty in osteonecrosis. A 2 to 10-year evaluation. Clin Orthop. 1997;334:116-123.

89. Arlot ME, Bonjean M, Chavassieux PM, Meunier PJ. Bone histology in adults with aseptic necrosis. Histomorphometric evaluation of iliac biopsies in seventy-seven patients. J Bone Joint Surg Am. 1983;65-A 1319-1327.

90. Ranawat CS, Atkinson RE, Salvati EA, Wilson PD Jr. Conventional total hip arthroplasty for degenerative joint disease in patients between the ages of forty and sixty years. J Bone Joint Surg Am. 1984;66A: 745-752.

91. Calder JD, Pearse MF, Revell PA. The extent of osteocyte death in the proximal femur of patients with osteonecrosis of the femoral head. J Bone Joint Surg Br. 2001;83:419-422.

92. Alpert B, Waddell JP, Morton J, Bear RA. Cementless total hip arthroplasty in renal transplant patients. Clin Orthop. 1992;284:164-169.

93. Dorr LD, Luckett M, Conaty JP. Total hip arthroplasties in patients younger than 45 years: a nine to ten year follow-up study. Clin Orthop. 1990;260:215-219.

94. Brinker MR, Rosenberg AG, Kull L, Galante JO. Primary total hip arthroplasty using noncemented porous-coated femoral components in patients with osteonecrosis of the femoral head. JArthroplasty. 1994;9 457-468.

95. Ritter MA, Meding JB. A comparison of osteonecrosis and osteoarthritis patients following total hip arthroplasty. Clin Orthop. 1998;206: 139-146.

96. Phillips FM, Pottenger LA, Finn HA, Vandermolen J. Cementless total hip arthroplasty in patients with steroid-induced avascular necrosis of the hip. A 62-month follow-up study. Clin Orthop Relat Res. 1994;303: 147-154.

97. Bradford DS, Janes PC, Simmons RS, Najarian JS. Total hip arthroplasty in renal transplant recipients. Clin Orthop Relat Res. 1983;181: $107-114$

98. Boettcher WG, Bonfiglio M, Hamilton HH, Sheets RF, Smith K. Non-traumatic necrosis of the femoral head. Part I. Relation of altered hemostasis to etiology. J Bone Joint Surg Am. 1970;52:312-321.
99. Hedley AK, Kim W. Prosthetic replacement in osteonecrosis of the hip. Instr Course Lect. 1983;32:265-271.

100. Devlin VJ, Einhorn TA, Gordon SL, Alvarez EV, Butt KM. Total hip arthroplasty after renal transplantation. Long-term follow-up study and assessment of metabolic bone status. J Arthroplasty. 1988;3: 205-213.

101. Yuan B, Taunton MJ, Trousdale RT. Total hip arthroplasty for alcoholic osteonecrosis of the femoral head. Orthopedics. 2009;32:400.

102. García-Ramiro S, Cofán F, Esteban PL, et al. Total hip arthroplasty in hemodialysis and renal transplant patients. Hip Int. 2008;18:51-57.

103. Bradford DS, Janes PC, Simmons RS, Najarian JS. Total hip arthroplasty in renal transplant recipients. Clin Orthop Relat Res. 1983;181:107-114.

104. Chmell SJ, Schwartz CM, Giacchino JL, Ing TS. Total hip replacement in patients with renal transplants. Arch Surg. 1983;118:489-495.

105. Deo S, Gibbons CL, Emerton M, Simpson AH. Total hip replacement in renal transplant patients. J Bone Joint Surg Br. 1995;77-B: 299-302.

106. Goffin E, Baertz G, Rombouts JJ. Long-term survivorship analysis of cemented total hip replacement (THR) after avascular necrosis of the femoral head in renal transplant patients. Nephrol Dial Transplant. 2006;21:784-788.

107. Cheng EY, Klibanoff JE, Robinson HJ, Bradford DS. Total hip arthroplasty with cement after renal transplantation. J Bone Joint Surg Am. 1995;77-A:1535-1542.

108. Murzic WJ, McCollum DE. Hip arthroplasty for osteonecrosis after renal transplantation. Clin Orthop Relat Res. 1994;299:212-219.

109. Kim Y-H, Park J-W, Joo J-H. Total hip replacement with a short metaphyseal-fitting anatomical femoral component. J Bone Joint Surg Br. 2011;93B:587-592.

110. Hanker GJ, Amstutz HC. Osteonecrosis of the hip in the sickle cell diseases. Treatment and complications. J Bone Joint Surg Am. 1988;70:499-506.

111. Acurio MT, Friedman RJ. Hip arthroplasty in patients with sickle cell hemoglobinopathy. J Bone Joint Surg Br. 1992;74:367-371.

112. Bishop AR, Roberson JR, Eckman JR, Fleming LL. Total hip replacement in patients who have sickle cell hemoglobinopathy. J Bone Joint Surg Am. 1988;70:853-855.

113. Clarke HJ, Jinnah RH, Brooker AF, Michaelson JD. Total replacement of the hip for avascular necrosis in sickle cell disease. J Bone Joint Surg Br. 1989;71:465-470.

114. Capello WN, D’Antonio JA, Feinburg JR, Manley MT, Naughton MT. Ceramic-on-ceramic total hip arthroplasty. J Arthroplasty. 2008;23: 39-43.

115. Kantor SG, Huo MH, Huk OL, Salvati EA. Cemented total hip arthroplasty in patients with osteonecrosis: a 6-year minimum follow-up study of second-generation cement techniques. J Arthroplasty. 1996;11:267-271.

116. Cornell CN, Salvati EA, Pellicci PM. Long-term follow-up of total hip replacement in patients with osteonecrosis. Orthop Clin North Am. 1985;16:757-769.

117. Katz RL, Bourne RB, Rorabeck CH, McGee H. Total hip arthroplasty in patients with avascular necrosis of the hip: follow-up observations on cementless and cemented operations. Clin Orthop Relat Res. 1992;281:145-151.

118. Kim YH, Oh SH, Kim JS, Koo KH. Contemporary total hip arthroplasty with and without cement in patients with osteonecrosis of the femoral head. J Bone Joint Surg Am. 2003;85:675-681.

119. Simon JP, Berger P, Bellemans J. Total hip arthroplasty in patients less than 40 years old with avascular necrosis of the femoral head. A 5 to 19-year follow-up study. Acta Orthop Belg. 2011;77: 53-60.

120. Garino JP, Steinberg ME. Total hip arthroplasty in patients with avascular necrosis of the femoral head: a 2- to 10-year follow-up. Clin Orthop Relat Res. 1997;334:108-115.

121. Kim YH, Kim JS, Park JW, Joo JH. Comparison of total hip replacement with and without cement in patients younger than 50 years of age: the results at 18 years. J Bone Joint Surg Br. 2011;93:449-455. 
122. Halley DK, Charnley J. Results of low friction arthroplasty in patients thirty years of age or younger. Clin Orthop Relat Res. 1975;112: 180-191.

123. Hozack WJ, Rothman RH, Booth RE Jr, Balderston RA, Cohn JC, Pickens GT. Survivorship analysis of 1,041 Charnley total hip arthroplasties. J Arthroplasty. 1990;5:41-47.

124. Kim YH, Oh JH, Oh SH. Cementless total hip arthroplasty in patients with osteonecrosis of the femoral head. Clin Orthop Relat Res. 1995;320:73-84.

125. Kim YG, Kim SY, Park BC, Kim PT, Ihn JC, Kim ID. Uncemented Harris-Galante total hip arthroplasty in patients with osteonecrosis of the femoral head. A 10-16-year follow-up study. Acta Orthop. 2005;76:42-48.

126. Ha YC, Kim HJ, Kim SY, Kim TY, Koo KH. THA using an anatomic stem in patients with femoral head osteonecrosis. Clin Orthop Relat Res. 2008;466:1141-1147.

127. Hartley WT, McAuley JP, Culpepper WJ, Engh CA Jr, Engh CA Sr. Osteonecrosis of the femoral head treated with cementless total hip arthroplasty. J Bone Joint Surg Am. 2000;82-A(10): 1408-1413.

128. Piston RW, Engh CA, De Carvalho PI, Suthers K. Osteonecrosis of the femoral head treated with total hip arthroplasty without cement. J Bone Joint Surg Am. 1994;76:202-214.

129. Boehler M, Knahr K, Plenk H Jr, Walter A, Salzer M, Schreiber V. Long-term results of uncemented alumina acetabular implants. J Bone Joint Surg Br. 1994;76:53-59.

130. Taylor AH, Shannon M, Whitehouse SL, Lee MB, Learmonth ID. Harris Galante cementless acetabular replacement in avascular necrosis. J Bone Joint Surg Br. 2001;83-B:177-182.

131. Eskelinen A, Remes V, Helenius I, Pulkkinen P, Nevalainen J, Paavolainen P. Uncemented total hip arthroplasty for primary osteoarthritis in young patients: a mid- to long-term follow-up study from the Finnish Arthroplasty Register. Acta Orthop. 2006;77: 57-70.

132. Hernandez JR, Keating EM, Faris PM, Meding JB, Ritter MA. Polyethylene wear in uncemented acetabular components. J Bone Joint Surg Br. 1994;76:263-266.

133. Wroblewski BM. 15-21 year results of the Charnley low-friction arthroplasty. Clin Orthop. 1986;211:30-35.

134. Hallan G, Lie SA, Havelin LI. High wear rates and extensive osteolysis in 3 types of uncemented total hip arthroplasty: a review of the PCA, the Harris Galante and the Profile/Tri-Lock Plus arthroplasties with a minimum of 12 years median follow-up in 96 hips. Acta Orthop. 2006;77:575-584

135. McCalden RW, MacDonald SJ, Rorabeck CH, Bourne RB, Chess DG, Charron KD. Wear rate of highly cross-linked polyethylene in total hip arthroplasty. a randomized controlled trial. J Bone Joint Surg Am. 2009;91:773-782.

136. Dorr LD, Wan Z, Shahrdar C, Sirianni L, Boutary M, Yun A. Clinical performance of a Durasul highly cross-linked polyethylene acetabular liner for total hip arthroplasty at five years. J Bone Joint Surg Am. 2005;87:1816-1821.

137. Thomas GE, Simpson DJ, Mehmood S, et al. The seven-year wear of highly cross-linked polyethylene in total hip arthroplasty: a doubleblind, randomized controlled trial using radiostereometric analysis. J Bone Joint Surg Am. 2011;93:716-722.

138. Mont MA, Seyler TM, Plate JF, Delanois RE, Parvizi J. Uncemented total hip arthroplasty in young adults with osteonecrosis of the femoral head: a comparative study. J Bone Joint Surg Am. 2006;88: 104-109.

139. McKellop HA. Bearing surfaces in total hip replacements: state of the art and future developments. Instr Course Lect. 2001;50: 165-179.

140. Dorr LD, Hilton KR, Wan Z, Markovich GD, Bloebaum R. Modern metal on metal articulation for total hip replacement. Clin Orthop Relat Res. 1996;333:108-117.
141. Dastane MR, Long WT, Wan Z, Chao L, Dorr LD. Metal-on-metal hip arthroplasty does equally well in osteonecrosis and osteoarthritis. Clin Orthop Relat Res. 2008;466:1148-1153.

142. Sieber HP, Rieker CB, Kottig P. Analysis of 118 second-generation metal-on-metal retrieved hip implants. J Bone Joint Surg Br. 1999;81:46-50.

143. Kim SY, Kyung HS, Ihn JC, Cho MR, Koo KH, Kim CY. Cementless Metasul metal-on-metal total hip arthroplasty in patients less than fifty years old. J Bone Joint Surg Am. 2004;86:2475-2481.

144. Park YS, Moon YW, Lim SJ, Yang JM, Ahn G, Choi YL. Early osteolysis following second-generation metal-on-metal hip replacement. J Bone Joint Surg Am. 2005;87:1515-1521.

145. Lachiewicz PF, Heckman DS, Soileau ES, Mangla J, Martell JM. Femoral head size and wear of highly cross-linked polyethylene at 5 to 8 years. Clin Orthop Relat Res. 2009;467:3290-3296.

146. Bitsch RG, Loidolt T, Heisel C, Ball S, Schmalzried TP. Reduction of osteolysis with use of marathon cross-linked polyethylene. A concise follow-up, at a minimum of five years, of a previous report. $J$ Bone Joint Surg Am. 2008;90:1487-1491.

147. Girard J, Bocquet D, Autissier G, Fouilleron N, Fron D, Migaud H. Metal-on-metal hip arthroplasty in patients thirty years of age or younger. J Bone Joint Surg Am. 2010;92:2419-2426.

148. McDonald SJ. Metal-on-metal total hip arthroplasty: the concerns. Clin Orthop Relat Res. 2004;429:86-93.

149. Oonishi H, Wakitani S, Murata N, et al. Clinical experience with ceramics in total hip replacement. Clin Orthop. 2000;379:77-84.

150. Clarke IC, Gustafson A. Clinical and hip simulator comparisons of ceramic-on-polyethylene and metal-on-polyethylene wear. Clin Orthop. 2000;379:34-40.

151. Hamadouche M, Boutin P, Daussange J, Bolander M, Sedel L. Alumina-on-alumina total hip arthroplasty: a minimum 18.5-year follow-up study. J Bone Joint Surg Am. 2002;84A:69-77.

152. Capello WN, D'Antonio JA, Feinberg JR, Manley MT, Naughton M. Ceramic-on-ceramic total hip arthroplasty: update. J Arthroplasty. 2008;23 Suppl 1:39-43.

153. Lusty PJ, Tai CC, Sew-Hoy RP, Walter WL, Walter WK, Zicat BA. Third-generation alumina-on-alumina ceramic bearings in cementless total hip arthroplasty. J Bone Joint Surg Am. 2007;89:2676-2683.

154. Yoo JJ, Kim YM, Yoon KS, Koo KH, Song WS, Kim HJ. Alumina-onalumina total hip arthroplasty. A five-year minimum follow-up study. J Bone Joint Surg Am. 2005;87:530-535.

155. Bierbaum BE, Nairus J, Kuesis D, Morrison JC, Ward D. Ceramicon-ceramic bearings in total hip arthroplasty. Clin Orthop. 2002;405: 158-163.

156. Bizot P, Nizard R, Lerouge S, Prudhommeaux F, Sedel L. Ceramic/ ceramic total hip arthroplasty. J Orthop Sci. 2000;5:622-627.

157. Sedel L. Evolution of alumina-on-alumina implants: a review. Clin Orthop. 2000;379:48-54.

158. Kim YH, Choi Y, Kim JS. Cementless total hip arthroplasty with ceramic-on-ceramic bearing in patients younger than 45 years with femoral-head osteonecrosis. Int Orthop. 2010;34:1123-1127.

159. Baek SH, Kim SY. Cementless total hip arthroplasty with alumina bearings in patients younger than fifty with femoral head osteonecrosis. J Bone Joint Surg Am. 2006;88:116-125.

160. Nich C, Sariali el-H, Hannouche D, et al. Long term results of aluminaon-alumina hip arthroplasty for osteonecrosis. Clin Orthop Relat Res. 2003;417:102-111.

161. Seyler TM, Bonutti PM, Shen J, Naughton M, Kester M. Use of an alumina-on-alumina bearing system in total hip arthroplasty for osteonecrosis of the hip. J Bone Joint Surg Am. 2006;88:116-125.

162. Garino JP. Modern ceramic-on-ceramic total hip systems in the United States: early results. Clin Orthop. 2000;379:41-47. 
Orthopedic Research and Reviews

\section{Publish your work in this journal}

Orthopedic Research and Reviews is an international, peer-reviewed, open access journal focusing on the patho-physiology of the musculoskeletal system, trauma, surgery and other corrective interventions to restore mobility and function. Advances in new technologies, materials, techniques and pharmacological agents are particularly welcome. The journal welcomes

original research, clinical studies, reviews \& evaluations, expert opinion and commentary, case reports and extended reports. The manuscript management system is completely online and includes a very quick and fair peer-review system, which is all easy to use. Visit http://www.dovepress. com/testimonials.php to read real quotes from published authors.

Submit your manuscript here: http://www.dovepress.com/orthopedic-research-and-reviews-journal 